\title{
Comparative Study on Mechanic Workshop Polluted Soil Treated With Lime (Citrus Aurantifolia) Juice, Powder and Inorganic Lime Fertilizer
}

\section{*1STEPHEN, E; ${ }^{2}$ OYEBAMIJI, OO; ${ }^{3}$ OTORKPA, OJ; ${ }^{1}$ LATENA, S; ${ }^{1}$ SUNDAY, AI; ${ }^{1}$ IDOKO, PA}

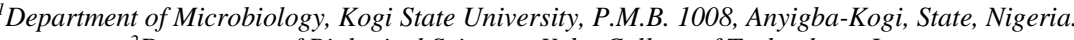 \\ ${ }^{2}$ Department of Biological Sciences, Yaba College of Technology, Lagos. \\ ${ }^{3}$ Texila American University, Georgetown, Guyana \\ *Corresponding Author Email: psychsea07@gmail.com
}

\begin{abstract}
An assessment of mechanic workshop polluted soil treated with $16.6 \%$ lime juice (MSAL), mechanic workshop polluted soil treated with lime powder (MSLP) and mechanic workshop polluted soil treated with inorganic lime fertilizer (MSLF) was conducted for a period of 56 days. The study revealed higher microbial counts in the treated soils compared to mechanic oil free soil (MFS). The total viable bacterial counts observed ranged from $1.6 \times 10^{4} \mathrm{cfu} / \mathrm{g}$ to $6.8 \times 10^{4}$ $\mathrm{cfu} / \mathrm{g}$ for MSF, $2.2 \times 10^{4} \mathrm{cfu} / \mathrm{g}-26.2 \times 10^{4} \mathrm{cfu} / \mathrm{g}$ for MSAL, $1.2 \times 10^{4} \mathrm{cfu} / \mathrm{g}-17.2 \times 10^{4} \mathrm{cfu} / \mathrm{g}$ for MSLP and $6.8 \times 10^{4} \mathrm{cfu} / \mathrm{g}-16.0$ $\times 10^{4} \mathrm{cfu} / \mathrm{g}$ for MSLF while fungi counts ranged from $2.5 \times 10^{4} \mathrm{cfu} / \mathrm{g}$ to $6.4 \times 10^{4} \mathrm{cfu} / \mathrm{g}$ for MFS, $4.0 \times 10^{4} \mathrm{cfu} / \mathrm{g}-16.4 \times 10^{4}$ $\mathrm{cfu} / \mathrm{g}$ for MSAL, $2.6 \times 10^{4} \mathrm{cfu} / \mathrm{g}-3.8 \times 10^{4} \mathrm{cfu} / \mathrm{g}$ for MSLP and $2.1 \times 10^{4} \mathrm{cfu} / \mathrm{g}-4.0 \times 10^{4} \mathrm{cfu} / \mathrm{g}$ for MSLF. Organisms isolated in the course of the study includes Pseudomonas sp, Staphylococcus sp, Bacillus sp, Micrococcus sp, Escherichia coli, Proteus sp, Aspergillus niger, Aspergillus fumigatus, Aspergillus flavus, Mucor sp, Saccharomyces sp, and Rhizopus sp. The physicochemical results showed that MSAL had higher moisture content, organic matter content, organic carbon, and nitrate than MSF, MSLP and MSLF. There were significant differences in $\mathrm{pH}$, organic matter content, organic carbon, nitrate and phosphorus at 0.05 probability level, but there was no significant different in the moisture content of the soil undergoing treatment. This is an indication that Lime juice has a greater potential in bioremediation of mechanic workshop polluted soil compared to lime powder and inorganic lime fertilizer.
\end{abstract}

\section{DOI: https://dx.doi.org/10.4314/jasem.v25i8.16}

Copyright: Copyright (c) 2021 Stephen et al. This is an open access article distributed under the Creative Commons Attribution License (CCL), which permits unrestricted use, distribution, and reproduction in any medium, provided the original work is properly cited.

Dates: Received: 10 May 2021; Revised: 28 June 2021; Accepted: 01 July 2021

Keywords: Lime juice, Lime powder, Lime fertilizer, mechanic workshop soil, hydrocarbon

Nigeria has witnessed increase in personal automobiles since independence. This increase correlates with the numbers of technicians and automobile workshops which are often not regulated (Abhulimhen, 2016). According to Ajao et al. (2011), Mechanic workshop is noted for high indiscriminate dumping of spent lubricating oil and other refined petroleum products such as fresh lubricating oil, diesel, grease, hydraulics and petrol. Umanu et al. (2013) are of the opinion that most automobile artisans are illiterates and are ignorant of the environmental implications of indiscriminate discharge of either fresh or used motor oil. Adewoyin et al. (2013) reported that motor oil may find its way to surface water and groundwater reserves which serves as source of potable water for community consumption. Stephen $e t$ al. (2013a) reported that the arrays of oil on mechanic workshop soil may have adverse effect on soil microbes as well as the physicochemical properties (e.g. pH) of the soil. Soil samples from mechanic workshops are usually hard, characterize by intense blackish colour due to long term exposure of the soil to spent oil accumulated over time and also devoid of plant life (Udeani et al., 2009). Most mechanic workshops are abandoned after a while and cannot be used for agricultural purposes (Stephen et al., 2013b, 2016a, 2019). Hence, the need to reclaim such mechanic workshop polluted soils for agricultural and aesthetic purposes. One of the means of reclaiming such soil is bioremediation. Bioremediation approaches have been reported severally in literature to be beneficial to the restoration of hydrocarbon polluted soil because of the cost implication and ecofriendly outcomes through the use of organic manures, compost, liming, inorganic lime fertilizers, plant derived green wastes and wood ash (Ulrici, 2000, Gallego et al., 2001, Adenipekun and Isikhuemhen, 2008, Akinde and Obire, 2008, Stephen et al., 2013b, Stephen and Temola, 2014, Stephen et al., 2015, 2016b, c, d). Stephen et al. (2016a, b, c) reported the use of lime juice, lime inorganic fertilizer in treatment of mechanic workshop and spent lubricating oil polluted soil. In 2019, Stephen et al. reported the use of lime powder in amending mechanic workshop 
polluted soil. The out come of these studies showed a favourable tilt towards improved microbiological and physicochemical properties of the polluted soil. Lime is a good source of proteins and dietary fibre which on decomposition yields more nitrate to the soil (Waghaye et al., 2019). Hence, this study seeks to compare the effect of natural lime products (Juice and pulverized lime peelings in form of powder) and inorganic commercial lime fertilizer to treat mechanic workshop polluted soil within a window of 56 days.

\section{MATERIALS AND METHODS}

Sample collection: Soil sample was collected from mechanic workshop close to the first gate of Kogi State University at surface depth of $0-10 \mathrm{~cm}$ (polluted soil) and also from hydrocarbon free soil behind Microbiology laboratory in Faculty of Natural Sciences, Kogi State University Anyigba.

Experimental design: Six (6) $\mathrm{kg}$ of the soil samples were weighed into four perforated plastic bowls (that is, three bowls contained mechanic workshop polluted soil and the fourth bowl was pristine soil). The sides and bases of the plastic bowls were perforated as described by Stephen et al. (2019). Mechanic oil free soil, MFS, contained oil free soil which served as the control (pristine soil), MSAL contained the mechanic workshop polluted soil treated with lime juice, MSLP contained the mechanic workshop polluted soil treated with lime powder $(1 \mathrm{~kg})$ and MSLF contained the mechanic workshop polluted soil treated with lime inorganic fertilizer $(1 \mathrm{~kg})$. MSAL contain one litre of extracted lime juice incorporated into the $6 \mathrm{~kg}$ of mechanic workshop soil to achieve a $16.6 \%$ amendment level while MSLP and MSLF were incorporated with $1 \mathrm{~kg}$ of pulverized lime peelings in form of powder and $1 \mathrm{Kg}$ of inorganic lime fertilizer (Confluence lime fertilizer, Anyigba) to achieve same $16.6 \%$ amendment level.

Culture condition and sampling: All The soil samples were kept in Microbiology laboratory Kogi State University, and were watered with 500 millilitres once a week for a period of eight (8) weeks. Sampling was conducted bi-weekly for period of 56 days ( 8 weeks) to determine the Microbiological components and physicochemical properties of the soil.

Microbiological and Physicochemical analysis: The soil samples were analyzed microbiologically as described by Public Health England (2014). The $\mathrm{pH}$ was determined as described by Nwinuka et al. (2003). Nitrate was determined by the micro Kjedahl method (Association of Official Analytical Chemist, AOAC, 2005). The phosphorus content and moisture were determined as described by Nwinuka et al., 2003).
Statistical Analysis: Descriptive statistics and analysis of variance (ANOVA) was performed using procedure of SPSS version 16 (2007). Experimental precision achieved was reported

\section{RESULTS AND DISCUSSION}

The total viable bacterial count from pristine soil (MFS), mechanic workshop polluted soil treated with Lime juice (MSAL), mechanic workshop polluted soil treated with Lime powder and mechanic workshop polluted soil treated with inorganic lime fertilizer (MSLF) is shown in figure 1. The total viable bacterial counts observed ranged from $1.6 \times 10^{4} \mathrm{cfu} / \mathrm{g}$ to $6.8 \times 10^{4}$ $\mathrm{cfu} / \mathrm{g}$ for $\mathrm{MSF}, 2.2 \times 10^{4} \mathrm{cfu} / \mathrm{g}-26.2 \times 10^{4} \mathrm{cfu} / \mathrm{g}$ for MSAL, $1.2 \times 10^{4} \mathrm{cfu} / \mathrm{g}-17.2 \times 10^{4} \mathrm{cfu} / \mathrm{g}$ for MSLP and $6.8 \times 10^{4} \mathrm{cfu} / \mathrm{g}-16.0 \times 10^{4} \mathrm{cfu} / \mathrm{g}$ for MSLF. The highest bacteria count was observed in MSLP at day 42 while the least counts were observed at days 28 and 56 in MFS. Higher bacteria counts were observed up till day 42 in MSLP compared to MSF, MSAL and MSLF. There was a gradual consistent increase observed in the bacterial population in MSAL reaching its peak at day 56. There were no significant differences in the bacteria counts observed in MFS, MSAL, MSLP and MSLF at $0.05 \%$ probability level. The higher bacteria counts observed in MSLP between days 0 and 42 in this study could be due to lower acidity of the lime peelings and the presence of natural polyphenols in the pulverized lime peelings which were used up by the bacteria (Stephen et al., 2019). The consistent increase in the bacterial population in MSAL till the end of the study could be attributed to the presence of natural biodegradable sugar present in the juice in a form that could easily be absorbed for a long time and the additional moisture added to the soil thereby increasing the water activity in the soil (Waghaye et al., 2019). Waghaye et al. (2019) reported $9.96 \%$ carbohydrate content in lime juice (4.1 $\%$ sugar). The bacteria population in MSAL, MSLP and MSLF reported in this study compared to MFS is in agreement with earlier works of hydrocarbon polluted soil amendments (Ijah and Antai, 2003, Akinde and Obire, 2008, Atagana, 2008, Chorom et al., 2010, Stephen and Temola, 2014, Stephen et al., 2015, Stephen et al., 2016, 2019). The organisms isolated were Pseudomonas sp, Staphylococcus sp, Bacillus sp, Micrococcus sp, Escherichia coli, Proteus sp. These organisms were previously isolated by Ijah and Antai (2003), Akinde and Obire (2008) and Stephen et al. (2015). They observed higher bacteria counts in hydrocarbon amended soil using poultry litter and inorganic fertilizer. Ekhaise and Nkwelle (2011) also isolated similar organisms from mechanic workshop soil. 
Figure 2 shows the total fungi count from unpolluted soil (MFS), mechanic workshop polluted soil treated with Lime juice (MSAL), mechanic workshop polluted soil treated with Lime powder and mechanic workshop polluted soil treated with inorganic lime fertilizer (MSLF). The total fungi counts ranged from $2.5 \times 10^{4} \mathrm{cfu} / \mathrm{g}$ to $6.4 \times 10^{4} \mathrm{cfu} / \mathrm{g}$ for MFS, $4.0 \times 10^{4} \mathrm{cfu} / \mathrm{g}$ $-16.4 \times 10^{4} \mathrm{cfu} / \mathrm{g}$ for MSAL, $2.6 \times 10^{4} \mathrm{cfu} / \mathrm{g}-3.8 \times 10^{4}$ $\mathrm{cfu} / \mathrm{g}$ for MSLP and $2.1 \times 10^{4} \mathrm{cfu} / \mathrm{g}-4.0 \times 10^{4} \mathrm{cfu} / \mathrm{g}$ for MSLF. The highest fungi count was observed in MSAL treatment compared to MSF, MSLP and MSLF. There were significant differences in the treatments-MSF, MSAL, MSLP and MSLF at 0.05 probability levels. The higher fungi count in MSAL compared to other treatments may be due to the acidic nature of the juice which favours the growth of fungi and the ease of assimilation of the readily available sugar substrate in the lime juice (Waghaye et al., 2019) compared to the lime powder and inorganic fertilizer that had to dissolve first before it can be assimilated and use for metabolic activities by the fungi. The isolates obtained were Aspergillus niger, Aspergillus flavus, Aspergillus fumigatus, Mucor sp, Saccharomyces sp, and Rhizopus sp. These isolates in addition to Trichoderma sp and Penicillium sp were isolated by Ekhaise and Nkwelle (2011) from mechanic workshop soil. Table 1 shows the physicochemical properties of the soil samples. The $\mathrm{pH}$ of the soil ranged from $5.63 \pm 0.63-7.30 \pm 056$. The highest $\mathrm{pH}$ was observed in MSLP while the least $\mathrm{pH}$ was observed in MSAL. There were significant difference in the $\mathrm{pH}$ between MFS, MSAL, MSLP and MSLF at 5\% probability level. The $\mathrm{pH}$ of the soil tends toward neutrality in the amended soil samples. These range of $\mathrm{pH}$, favours biodegradation of hydrocarbon products (Stephen and Temola, 2014).

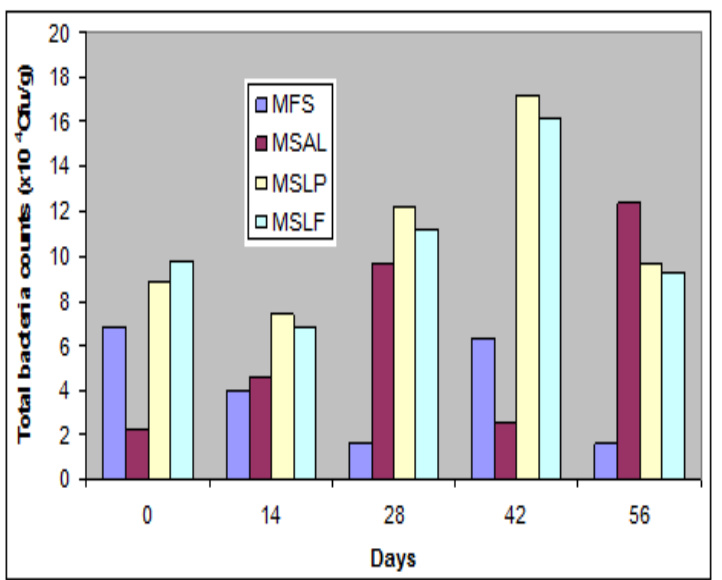

Fig 1: Total bacteria count in mechanic workshop soil undergoing treatment

MFS: Mechanic oil free soil, MSAL: Mechanic workshop polluted soil treated with lime juice, MSLP: Mechanic workshop polluted soil treated with lime powder, MSLF: Mechanic workshop polluted soil treated with inorganic lime fertilizer

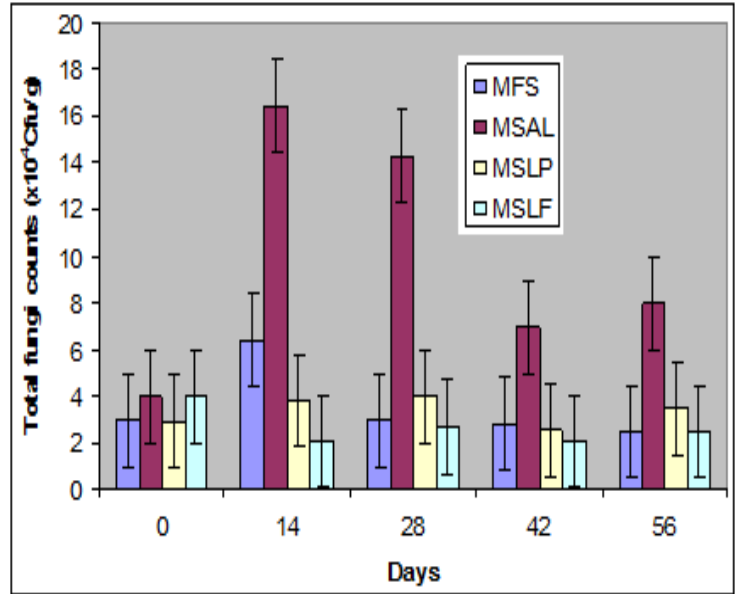

Fig 2. Total fungi counts in mechanic workshop soil undergoing treatment

MFS: Mechanic oil free soil, MSAL: Mechanic workshop polluted soil treated with lime juice, MSLP: Mechanic workshop polluted soil treated with lime powder, MSLF: Mechanic workshop polluted soil treated with inorganic lime fertilizer

Moisture content ranged from $7.36 \pm 3.08 \%$ to $13.00 \pm$ $2.04 \%$. The highest moisture content was observed in MSAL compared to MFS, MSLP and MSLF. There was no significant difference in the moisture content between MFS, MSAL, MSLP and MSLF at 0.05 probability level. The higher moisture content observed in the mechanic workshop polluted soil treated with Lime juice (MSAL) compared to oil free soil (MFS) and other treatments could be due to the fluid nature of the juice conferring more moisture to the soil. According to Waghaye et al. (2019), lime juice contains $83.88 \%$ moisture content. This trend was observed by Stephen et al. (2016a) and is in agreement with earlier findings of Stephen and Egene (2012) who observed higher moisture content in spent lubricating oil polluted soil receiving extra water. The organic matter content ranged from $1.30 \pm 0.23 \%-$ $7.70 \pm 2.80 \%$ while the organic carbon ranged from $0.75 \pm 0.13 \%$ to $13.28 \pm 0.43 \%$. Organic matter content and organic carbons were both higher in MSAL followed by MSLP and MSLF. There were significant differences in MSF, MSAL, MSLP and MSLF in both organic matter content and organic carbon at $5 \%$ probability levels. The higher organic matter and organic carbon observed in this study may stem from the plant derived sources (Stephen et al., 2016a, 2019). The results also show that green wastes contribute more organic matter and organic carbon than inorganic fertilizer to soil. Mbah et al.,(2006, 2009) are of the opinion that increased in organic matter and organic carbon in hydrocarbon polluted soil may be beneficial to soil physico- chemical properties . They reported that organic matter and organic carbon from organic wastes can influence the ability of microorganisms to degrade hydrocarbon pollutants.

STEPHEN, E; OYEBAMIJI, OO; OTORKPA, OJ; LATENA, S; SUNDAY, AI; IDOKO, PA 
The nitrate content was higher in MSAL compared to MFS, MSLP and MSLF. The nitrate content ranged from $0.04 \pm 0.01 \%$ to $1.04 \pm 0.45 \%$. There were significant differences in the nitrate concentration between MFS, MSAL, MSLP and MSLF at 5\% probability limit. The higher nitrate in MSAL may be due to increase rate of organic matter decomposition in the treatment occasion by liquid substrate and natural occurring sugar in the juice. Stephen et al. (2016a) observed similar trend in the use of lime juice to amend mechanic workshop polluted soil. This finding is in agreement with Atagana (2008), Tanee and Kinako (2008) and Mbah et al. (2009). They all reported higher nitrate concentration in hydrocarbon polluted soil exposed to compost and organic manure.

Table 1. Physicochemical qualities of Mechanic workshop soil undergoing bioremediation (M+SE)

\begin{tabular}{lllll}
\hline Parameter & MFS & MSAL & MSLP & MSLF \\
\hline $\mathrm{pH}$ & $6.49 \pm 0.27^{\mathrm{a}, \mathrm{b}}$ & $5.63 \pm 0.63^{\mathrm{b}}$ & $7.36 \pm 0.56^{\mathrm{a}}$ & $6.64 \pm 0.30^{\mathrm{a}, \mathrm{b}}$ \\
Moisture, \% & $7.36 \pm 3.05^{\mathrm{a}}$ & $13.00 \pm 2.04^{\mathrm{a}}$ & $11.70 \pm 2.00^{\mathrm{b}}$ & $9.77 \pm 2.22^{\mathrm{a}}$ \\
O. M. C \% & $1.30 \pm 0.23^{\mathrm{b}}$ & $7.70 \pm 2.80^{\mathrm{a}}$, & $2.80 \pm 0.21^{\mathrm{b}}$ & $2.72 \pm 0.20^{\mathrm{b}}$ \\
O. C \% & $0.75 \pm 0.13^{\mathrm{c}}$ & $3.28 \pm 0.43^{\mathrm{a}}$ & $1.73 \pm 0.07^{\mathrm{b}}$ & $1.60 \pm 0.11^{\mathrm{b}}$ \\
Nitrate \% & $0.10 \pm 0.02^{\mathrm{b}}$ & $1.04 \pm 0.45^{\mathrm{a}}$ & $0.04 \pm 0.01^{\mathrm{b}}$ & $0.31 \pm 0.06^{\mathrm{b}}$ \\
Phosphate, $\%$ & $8.23 \pm 0 . \mathrm{c}$ & $9.31 \pm 2.34^{\mathrm{a}, \mathrm{b}}$ & $12.90 \pm 0.81^{\mathrm{a}}$ & $9.39 \pm 0.82^{\mathrm{a}, \mathrm{b}}$ \\
\hline
\end{tabular}

a: same superscripts along the same row are not significantly $(p<0.05)$ different. Values are mean of five replicates. \% (percentage), MFS: Mechanic oil free soil, MSAL: Mechanic workshop polluted soil treated with lime juice, MSLP: Mechanic workshop polluted soil treated with lime powder, MSLF: Mechanic workshop polluted soil treated with inorganic lime fertilizer

Phosphate content ranged from $8.23 \pm 0.96 \%$ to 12.90 $\pm 0.81 \%$.The soil amended with Lime powder (MSLP) had higher phosphate content $(12.90 \pm 0.81 \%$.) followed by MSLF $(9.39 \pm 0.82 \%)$ while the least phosphate concentration was observed in MSF (8.23 \pm $0.96) \%$.There were significant differences in the phosphate content between MFS, MSAL, MSLP and MSLF at 0.05 probability limit. Stephen et al. (2019) reported high phosphate content in lime powder $(22.10 \%)$ used to amend mechanic workshop polluted soil. Czech et al. (2020) obtained similar result from citrus fruits. They reported $20.1 \%$ phosphorus content in lime peelings. High nitrate and phosphate concentration are beneficial to bio-stimulation of hydrocarbon enriched soil.

Conclusion: This study showed that lime juice had the potential to sustain bacteria population over a long period of time and more favourable for fungi growth compared to lime powder and inorganic lime fertilizer. The physicochemical parameters of the soil showed that MSAL had higher moisture content, organic matter content, organic carbon, and nitrate than MSF, MSLP and MSLF. This is an indication that Lime juice has a greater potential in bio-stimulation of mechanic workshop polluted soil compared to lime powder and lime inorganic fertilizer.

\section{REFERENCES}

Abhulimhen, BI (2016). Physico-chemical properties of soil sourced from automobile mechanic workshop in ikoku mechanic village, mile 3 Diobu, Port- Harcourt, Rivers State, Nigeria. A Research project submitted to the Department of Science Laboratory Technology (Geology and mining technology option), Faculty of Science, University of Port -Harcourt, Nigeria.
Adenipekun, CO; Isikhuemhen, O S (2008). Bioremediation of engine oil polluted soil by the tropical white rot fungus, Lentinus squarrosulus Mont (Singer). Pakistani J. of Bio Sci. 11, 1634-1637.

Adewoyin, O A; Hassan, AT ; Aladesida, AA (2013). The impacts of auto-mechanic workshops on soil and groundwater in Ibadan metropolis. Afri J. of Environ Sci and Tech. 7(9):891-898

Ajao, AT; Oluwajobi, AO ; Olatayo,VS (2011). Bioremediation of Soil Microcosms from AutoMechanic Workshops. J. Appl. Sci. Environ. Manage. 15 (3): $473-477$

Akinde, SB ; Obire, O (2008) Aerobic heterotrophic bacteria and petroleum utilizing-bacteria from cow dung and poultry manure. World J. Micro and Biotech. 24, 1999-2002.

Atagana, HI (2008). Compost bioremediation of hydrocarbon contaminated soil inoculated with organic manure. Afri.J. of Biotech, 7(10): 1516-1525

Association of Official Analytical Chemist. (AOAC, 2005). Method of analysis, Washington D.C.

Chorom, M; Sharifi, HS; Motamedi, H (2010). Bioremediation of a crude oil-polluted soil by application of fertilizers. Iranian J. of Environ. Health Sci and Eng 7. : $4.319-326$.

Czeck, A; Zarycka, E; Yanovych, D; Zasadna, Z; Grzegorczyk, I; Klys, S (2020). Mineral content of the pulp and peel of various citrus fruit cultivars. Bio. Trace Element Res. 193: 555-563.

Ekhaise, FO ; Nkwelle, J (2011). Microbiological and physicochemical analyses of oil contaminated soil 
from major motor mechanic workshops in Benin City metropolis, Edo State, Nigeria. J. Appl. Sci. Environ. Manage. 15 (4): $597-600$.

Gallego, JLR; Loredo, J; Llamas, JF; Vazquez, F ; Sanchez, J (2001). Bioremediation of dieselcontaminated soils: evaluation of potential in situ techniques by study of bacterial degradation. Biodegrad, 12: 325-335

Ijah, UJJ; Antai, SP (2003). The potential use of chickendrop micro-organisms for oil spill remediation. Environ: 23(1):89-95

Mbah, CN; Nwite, JN; Okporie, OE (2006) Effect of organic waste on some physicochemical properties and productivity of spent oil ultisol in Abakaliki , Nigeria. Nig J. of Trop Agric. 8:51-56

Mbah, CN; Nwite, JN; Nweke, IA (2009) Amelioration of spent oil contaminated ultisol with organic waste and its effects on soil properties and maize (Zea mays L) yield. World J. of Agric Sci. 5(2): 163-168

Nwinuka, NN; Essien, BE; Osuji, CL (2003). Soil Analysis. In: Research Techniques in Biological and Chemical Sciences (Onyeike, E.N and Osuji, J.O editors), 1st Edition, Springfield Publishers Ltd, Owerri, pp: 369-402.

Public Health England. (2014). Preparation of samples and dilutions, plating and subculture. Microbiology Services. Food, Water and Environmental Microbiology Standard Method FNES26 (F2); Version

Stephen, E; Egene, U M (2012). Microbiology and Physicochemical Properties of Soil Polluted with lubricating oil in Anyigba Kogi state Nigeria. Nig. J. of Tech. Res. 7(2), 49-52

Stephen, E; Ekwetafia, BE; Esemikose, EE; Akogu, EA; Abioye, OP (2013a). Microbiology and physicochemical properties of mechanic workshop polluted soil amended with cowpea chaff in Anyingba, Kogi State, Nigeria. Malay. J. Sci, 32 (1), 3-8

Stephen, E; Job, OS; Abioye, OP (2013b). Study on Biodegradation of Diesel contaminated soil amended with cowpea chaff. J. of Sci. and Mult. Res, 2(1):14-18

Stephen, E; Temola. OT (2014). Enhanced Biodegradation of Spent Lubricating Oil Contaminated Soil using Poultry Litter. Brit. Biotec., 4(8): 868-876

Stephen, E; Okwute, LO ; Okai, AI (2015). Bioremediation of mechanic workshop polluted soil amended with poultry litter. Bio-sci Res in Today's World 1(1): 77- 83
Stephen, E; Otorkpa, OJ; Adejo, PO ; Shaibu, L (2016a). Preliminary study of mechanic workshop soil amended with juice extracted from Lime (Citrus aurantifolia). $J$ of Bio-sci and Biotech Discov, 1: 83-88

Stephen, E; Obaka, SL; Ekeyi, D (2016b). Bioremediation of spent lubricating oil Contaminated soil by amendment with lime fertilizer. FUW Trends in Sci. Tech, 1(2): $567-569$.

Stephen, E; Okwute, LO; Idoko, PA; Makolo, D (2016c).Study on Biodegradation of Mechanic Workshop Polluted Soil Amended with Lime Fertilizer. Int. J. of Environ. Monit. and Anal. 4(1): 2126

Stephen, E; Okwute, LO; Peter, JO; Ekeyi, D (2016d). Microbiological and physicochemical studies of spent lubricating oil contaminated soil amended with wood ash. J.of Bio-sci and Biotech. Disco, 1: 36-41.

Stephen, E; Okwute, LO; Otorkpa, OJ; Sunday, IA (2019). A Study on Mechanic Workshop Polluted Soil Amended With Green Waste (Citrus Aurantifolia Powder). FUW Trends in Sci. \& Tech 4 (2): 409-412.

Tanee, FBG; Kinako, PDS (2008). Comparative study of Biostimulation and phytoremendiation in the mitigation of crude oil toxicity in tropical soil. J.of App. Sci. and Environ. Manage. 12(4): 143-147.

Udeani, TKC; Oboroh, AA; Okwuosa, CN; Achukwu, PV; Azubike, N (2009). Isolation of bacteria from mechanic workshops soil environment contaminated with used engine oil. Afri. J. Biotech., 8 (22): 63016303.

Ulrici, W (2000). Contaminated soil areas, different countries and contaminant, monitoring of contaminants, in Environmental processes II-Soil decontamination, vol XI, edited by H. J. Rehm and G. Reed. Wiley-VCH, New York. pp. 5-42.

Umanu, G; Nwachukwu, SCU; Olasode, OK (2013). Effects of cow dung on microbial degradation of motor oil in lagoon water. Glo. J. of Bio-Sci. and Biotech. 2 (4): $542-548$

Waghaye, SY; Kshirsagar, RB; Sawate, AR; Mohammed, S (2019). Studies on Physical and Chemical composition of Lime (Citrus aurantifolia L). Int. J. of Chem. Stud. 7 (2): 1098-1100 